\title{
Intracranial Infection of Mice with Bordetella pertussis
}

\author{
By M. C. BERENBAUM, J. UNGAR AND W. K. STEVENS \\ Glaxo Laboratories Limited, Greenford, Middlesex
}

\begin{abstract}
SUMMARY: A bacteriological and histological study was made of the sequence of events in unprotected and protected mice, after intracranial challenge with Bordetella pertussis. No difference in the results was obtained whether mice were injected through the parietal bone or through the foramen magnum. Injected material was distributed throughout the subarachnoid space and ventricles. In unprotected mice organisms multiplied continuously until death. Bacterial multiplication was limited to the cranial cavity, in which it was practically confined to the ciliated layer over the ependyma. There was no invasion of the brain substance. The histological changes in the brain included purulent meningitis, choroiditis, polymorphonuclear infiltration of perivascular spaces and cerebral substance, haemorrhages, hydrocephalus and necrosis of nerve cells. In protected mice there was a brief initial multiplication of organisms and then their rapid elimination. Histologically the brains of immune mice after challenge were characterized by an intense mononuclear-cell response, which persisted for $2-3$ weeks, subsiding slowly during the following 10 weeks.
\end{abstract}

The mouse intracerebral protection test for pertussis vaccine (Kendrick, Eldering, Dixon, \& Misner, 1947) depends on the ability of immune mice to resist intracerebral challenge with living Bordetella pertussis. Since the efficacy of pertussis vaccines in clinical practice has been found to be well correlated with the results of this test (Medical Research Council, 1956), it was thought desirable to study its underlying mechanisms.

\section{METHODS}

Test animals. Albino mice closely inbred from Strong $\mathbf{A}_{2}$ ancestors were used; they were of either sex, 6-7 weeks old, weighing 15-20 g. They were fed on M.R.C. diet no. 41.

Challenge dose. Kendrick's original strain of Bordetella pertussis (18-323) was recovered from freeze-dried cultures by plating on Bordet-Gengou medium. After incubation for $48 \mathrm{hr}$. at $37^{\circ}$ the growth of organisms was washed off in saline and dispersed with the aid of glass beads. The suspension was diluted in a mixture of equal parts of normal saline and nutrient broth to contain 100,000 organisms/ml., standardized photometrically. Viable counts indicated that the number of live organisms in this suspension varied from 58,000 to $103,000 / \mathrm{ml}$.

Vaccines. These were prepared from $48 \mathrm{hr}$. cultures of virulent strains grown on Bordet-Gengou medium or in a partially defined medium (Ungar, James, Muggleton, Pegler \& Tomich, 1950) and were killed with formalin or ultraviolet radiation and preserved with thiomersalate (1/7500). For immunization mice were injected intraperitoneally 2 weeks before challenge with $1000 \times 10^{6}$ organisms in $0 \cdot 1 \mathrm{ml}$. saline. 


\section{$314 \quad$ M. C. Berenbaum, J. Ungar and W. K. Stevens}

Method of challenge. Kendrick, and many investigators since, injected the challenge dose into the brain through the parietal bone. We found it economical of time and animals to inject through the foramen magnum. The mice were lightly anaesthetized with ether and placed prone on a convenient flat surface. The head was grasped between finger and thumb of the left hand, and, while being kept horizontal, was raised about a centimetre off the table. Injection was made with a $1 \mathrm{ml}$. tuberculin syringe carrying a half-inch 20-gauge needle which was inserted forwards and slightly downwards into the foramen magnum at an angle of about $30^{\circ}$ above the horizontal. Forward progression of the needle was stopped immediately a slight 'give' was felt, by which the entry of the needle tip into the cisterna magna was detected. The injected volume was $0.05 \mathrm{ml}$., containing 5000 organisms.

Few deaths resulted from this procedure. Occasionally mice were killed immediately or died in the next few days with obvious signs of brain damage, such as rolling and twisting movements. Mice which died up to the fourth day after injection were excluded from the test, since their death was considered to be due to the trauma of injection.

Bacterial counts. At intervals after injection, animals were killed by traction on the neck, their organs removed aseptically and ground in a Potter mill with saline. Single brains were ground in $5 \mathrm{ml}$. saline, pooled groups of 5 brains in $15 \mathrm{ml}$., livers in $2 \mathrm{ml}$. and spleen and lung in $1 \mathrm{ml}$. Blood was obtained from the right ventricle. Cranial washings were obtained by flushing out the cranial cavity with $0.25 \mathrm{ml}$. saline after removal of the brain.

Serial tenfold dilutions of the above-named materials were made in saline and $0.02 \mathrm{ml}$. drops from a standard dropper plated on Bordet-Gengou medium within 5 min. of making the dilutions. Each specimen was plated in triplicate. After incubation at $37^{\circ}$ for 4 days, the number of colonies was counted, and the number of organisms $/ 0.02 \mathrm{ml}$. drop calculated.

Histological methods. Animals were killed by decapitation at intervals after injection of virulent bacterial suspensions or, in controls, of equal volumes of broth saline. Tissues were fixed in $10 \%(\mathrm{v} / \mathrm{v})$ commercial formalin in $0.85 \%$ saline kept over marble chips, or in Zenker-formol and embedded in paraffinwax.

Sections were stained with Celestin blue-haemalum-azophloxine and Giemsa; and, when required, with Loyez's haematoxylin, Mallory's phosphotungstic acid-haematoxylin, Mallory's trichrome, acid picro-Mallory, Gomori's reticulin method, Pickworth's benzidine stain, Pearse's periodic acid-Schiff trichrome (Pearse, 1953) or copper phthalocyanin-neutral red (Pearse, 1956). Formalin-fixed frozen sections were stained with Fettrot 7 B-haemalum (Pearse, 1953). For certain studies frozen sections of adrenal glands were stained for acid and alkaline phosphatase and non-specific esterase (Pearse, 1953) and for succinic dehydrogenase by the method of Pearson \& Defendi (1954) with added cyanide (Rosa \& Velardo, 1954).

Distribution of the injected material. Since it was not possible to study by standard cultural or histological methods the distribution of the small bacterial inoculum used (see below), it was necessary to use instead indian ink 
(diluted 1/4 with saline) or dense suspensions of stained organisms. These were injected in $0.05 \mathrm{ml}$. volumes and the animals immediately killed. The heads were skinned, fixed and decalcified. Some were sliced by hand with a razor and examined with a stereoscopic microscope; others were examined in paraffin or frozen section.

Investigation of the blood-brain barrier. The animals used in this experiment were either uninfected controls or mice which had been injected with 5000 Bordetella pertussis organisms via the foramen magnum 6 days previously.

Radio-iodinated human serum albumin (from the Radiochemical Centre, Amersham) having a specific activity at the time of use of $25 \mu \mathrm{C} . / \mathrm{mg}$. was diluted in normal saline so that $1 \mathrm{ml}$. contained $200-300 \mu \mathrm{C}$. Mice were injected with $0.1 \mathrm{ml}$. intraperitoneally and killed at intervals and the radioactivity of the serum and brains measured by using a type $\mathbf{M} 6 \mathrm{H}$ liquid counter. The brains were homogenized in normal sodium hydroxide for this purpose.

\section{RESULTS}

With the exception of those animals which suffered significant immediate brain trauma, mice challenged intracranially recovered rapidly and appeared well until the 4th or 5th day. A progressive illness then began, in which the mice became lethargic and dehydrated. Terminally they showed signs of meningeal irritation and brain damage, such as hyperextension of the neck, excessively violent motor activity when disturbed, rolling and twisting movements and running movements made with the legs in the air. In a typical experiment deaths began on the 6th day and all mice were dead by the 8 th day. Inaccuracies in the challenge dose caused some variation; sometimes deaths began on the 5th day and on other occasions not all mice were dead until the 10th day after challenge. Mice which had been effectively immunized showed no evidence of illness.

\section{Distribution of the injected material}

Indian ink or stained bacteria injected through the foramen magnum were distributed throughout the subarachnoid space and ventricles. Material accumulated especially on the ventral aspect of the brain, and here a little penetrated along a few perivascular spaces into the cerebrum and hypothalamus; some also passed along the sheaths of the second and eighth nerves up to the eyeball and inner ear, respectively. Injected material was also seen in the diploic and dural venous sinuses and in the veins of the nasal septum and turbinates. Distribution was similar when material was injected through the parietal bone, except that the lateral ventricle on the side of the injection contained much more material than did the contralateral ventricle.

\section{Histological changes in unprotected mice}

Brain. Twenty-four hours after injection of the challenge dose there was a polymorph reaction in the meninges, especially at the base of the brain and in the choroid plexuses. The latter showed polymorphs crowding the vessels, 


\section{6}

M. C. Berenbaum, J. Ungar and W. K. Stevens

infiltrating the connective tissue stroma and occasionally migrating between the epithelial cells. Organisms were not found. In controls injected with broth saline the picture was indistinguishable from that described above, which therefore seems to be a reaction to the suspending medium.

Two days after injection appearances had not changed significantly, except that scanty organisms might be found lying on the ependyma of the lateral and third ventricles (Pl. 1, fig. 1 ). In the controls the only abnormality was an occasional polymorph in the interstitial tissue of the choroid plexuses.

On the 3rd day the choroid plexuses were crowded with polymorphs. Many polymorphs lay free in the ventricles and there was a moderately dense polymorph exudate in the basal meninges (Pl. 2, fig. 8). Vessels in the thalamus and hypothalamus and around the lateral ventricles were cuffed by polymorphs, a few of which had invaded the cerebral substance (Pl. 1, fig. 3). Some clusters of organisms were seen, mainly in the supra-optic recess of the third ventricle, where they lay on the ependyma. A few cells in the lateral ventricular choroid plexuses (one or two/section) had engulfed groups of organisms. The brains of controls were now quite normal in appearance, and remained so for the rest of the experiment.

On the 4th day polymorph infiltration was more marked. Occasional brains showed a few small haemorrhages in the thalamus and hypothalamus, and slight dilatation of the ventricles. Many clumps of organisms were present in the ventricles, mainly entangled in the ependymal cilia (Pl. 1, fig. 4), but some were seen within ependymal cells.

On the 5th day haemorrhages were seen in all the brains examined, most frequently in the hypothalamus, thalamus, hippocampus, cerebellum, corpus callosum, tapetum and the deepest layers of the cerebral cortex (Pl. 1, fig. 6). These haemorrhages were generally ball-shaped, although they were sometimes elongated in the direction of a fibre-tract and sometimes evidently related to a small vessel. Hydrocephalus was seen more frequently, and in some brains there was necrosis and loss of nerve cells in the pyramidal cell layer of the hippocampus and the granular layer of the cerebellar cortex (Pl. 1, fig. 5).

On the 6th day the ventricles in all brains were distended by purulent fluid (Pl. 1, fig. 6), and there was extensive polymorph invasion of the brain substance, which appeared to be undergoing liquefaction necrosis in places, especially around the ventricles. Necrosis of nerve cells in the hippocampus was seen more often, and in some brains the epithelium of the lateral ventricular choroid plexuses was stretched over underlying collections of polymorphs. There were enormous numbers of organisms in the ventricles, forming a thick and continuous layer on the ependyma and lying in the ventricular cavity, either free or engulfed by polymorphs (Pl. 2, fig. 7). Smaller numbers were adherent to the epithelium of the choroid plexuses, and very few organisms were seen in the meninges. Prolonged search revealed occasional bacteria in perivascular spaces near the ventricles or the surface of the brain, but no organisms were ever seen within the cerebral substance.

On succeeding days the lesions increased in severity, the brain being riddled with haemorrhages and infiltrated with polymorphs, the ventricles 
coated with organisms and distended with pus and the meninges and choroid plexuses grossly inflamed.

Lesions made by the needle during injection were seen in the pons, medulla or cerebellum of some of the brains injected via the foramen magnum and in the cerebrum of all the brains injected via the parietal bone. Such lesions were characterized by local haemorrhage and proliferation of glial cells. No bacteria were found in these areas. Apart from the situation of the needle track, no consistent difference was noted between mice injected through the foramen magnum and those injected through the parietal bone. The incidence of these changes is recorded in Table 1.

\section{Table 1. Incidence of histological findings in unprotected mice after challenge with 5000 Bordetella pertussis organisms}

The figures refer to the number of brains in which the changes were seen out of five examined on each day.

Time after challenge (days):
Meningitis
Organisms seen
Vascular cuffing
Haemorrhages
Hydrocephalus
Necrosis of nerve cells
Liquefaction of brain substance

$\begin{array}{llllllll}\cdots & \mathbf{1} & \mathbf{2} & \mathbf{3} & \mathbf{4} & \mathbf{5} & \mathbf{6} & \mathbf{7} \\ & \mathbf{5} & \mathbf{5} & \mathbf{5} & \mathbf{5} & \mathbf{5} & \mathbf{5} & \mathbf{5} \\ & \mathbf{0} & \mathbf{2} & \mathbf{5} & \mathbf{5} & \mathbf{5} & \mathbf{5} & \mathbf{5} \\ & \mathbf{0} & \mathbf{0} & \mathbf{5} & \mathbf{5} & \mathbf{5} & \mathbf{5} & \mathbf{5} \\ \mathbf{0} & \mathbf{0} & \mathbf{0} & \mathbf{1} & \mathbf{5} & \mathbf{5} & \mathbf{5} \\ & \mathbf{0} & \mathbf{0} & \mathbf{0} & \mathbf{1} & \mathbf{2} & \mathbf{5} & \mathbf{5} \\ & \mathbf{0} & \mathbf{0} & \mathbf{0} & \mathbf{0} & \mathbf{1} & \mathbf{2} & \mathbf{4} \\ \mathbf{0} & \mathbf{0} & \mathbf{0} & \mathbf{0} & \mathbf{0} & \mathbf{5} & \mathbf{5}\end{array}$

Adrenal glands. One or two days after the injection of either the challenge dose or broth saline, there was slight to moderate lipid depletion affecting the outer zona fasciculata. Lipid distribution returned to normal by the third day and remained so in control mice. In challenged mice there was, on the 5th day, a sudden and marked depletion of lipid in the outer fasciculata, which increased on subsequent days until by the 7th and 8th day only small areas of the zona glomerulosa and of the innermost part of the cortex retained lipid. Staining for succinic dehydrogenase, non-specific esterase and acid phosphatase showed increased amounts of all three in the cortex, as compared with controls. (In the test for alkaline phosphatase non-specific staining prevented assessment of the results.) It may be concluded that, in the terminal stages of the illness, there was also increased activity of the adrenal cortex. That there was also increased activity of the medulla is shown by the appearance here of a few mitotic figures on the 7 th and 8 th days.

Other organs. The only finding of note was terminal fatty change in the liver and atrophy of the lymphoid follicles of the spleen. The lungs, heart, kidneys and pancreas were normal.

\section{Histological changes in protected mice}

One day after challenge there was a cellular reaction in the meninges, equal in intensity to that occurring in unprotected mice. It consisted predominantly of polymorphs, but a few lymphocytes and large mononuclear cells were also present. The cellular reaction did not subside, but became 
increasingly mononuclear until, by the 5th day, mononuclear cells predominated. The cells were mainly lymphocytes, with some large mononuclear cells, arachnoidal cells and polymorphs. By the 6th day there was an intense mononuclear cell infiltration of the meninges (Pl. 2, fig. 8) and, in some brains, of the choroid plexuses. Perivascular cuffing with mononuclear cells was also seen (Pl. 9, fig. 9). The exudate now included numerous immature and mature plasma cells, some of which were binucleate ( $\mathrm{Pl} .2$, fig. 10). Local multiplication of cells was shown by the occasional mitotic figure (Pl. 2, fig 11).

Small granulomata were formed, superficial or deep to the lining of the fourth ventricle and in the choroid plexuses. They were composed of lymphocytes, large mononuclear cells and some cells resembling the epithelioid cells of tuberculosis (Pl. 2, fig. 12). This reaction persisted for approximately 23 weeks after challenge and then slowly subsided. Six weeks after challenge there was still moderate cellular infiltration of the meninges and choroid plexuses, and there might be persisting granulomata and vascular cuffing with lymphocytes. At 13 weeks after challenge there was still some excess of lymphocytes, large mononuclear cells and plasma cells in the meninges and choroid plexuses. Organisms were seen only on the 4th and 5th days after injection. These were very few, mainly lying on the ependyma, occasional organisms lying within polymorphs.

\section{Bacterial growth in unprotected mice}

At $1 \mathrm{~min}, 1 \mathrm{hr}$ or $24 \mathrm{hr}$. after injection of 5000 organisms, none could be cultured from the brain, blood, lungs or spleen, neither was it possible to trace such a small number by conventional histological methods. This lagphase ended after $24 \mathrm{hr}$. and by $48 \mathrm{hr}$. after challenge rapid multiplication had occurred, about $1 \times 10^{5}$ organisms being recovered from each brain. Growth tended to level off after the fifth day at between $1 \times 10^{8}$ and $1 \times 10^{9}$ organisms/ brain. Fig. 1 shows a typical set of brain counts. Repeated examinations showed that, with this challenge dose, no bacteria could be detected throughout the course of the infection in the blood, lung, spleen or liver, even in the terminal stages, and growth appeared to be limited to the cranial cavity. The numbers of organisms recovered by washing out the cranial cavity after removal of the brain amounted to $0 \cdot 1-1.0 \%$ of those in the brain. Since the experiments with indian ink or stained bacteria showed that some of the injected material entered the blood stream, mice were injected with $100 \times 10^{6}$ organisms and organs cultured $1 \mathrm{hr}$ later. It was found that small numbers of organisms could be cultured from the spleen, lung and heart blood, but that these together accounted for less than $1 \%$ of those recovered, the vast majority being found in the brain.

\section{Bacterial growth in protected mice}

Fig. 2 compares the changes found in a typical experiment in which unprotected and protected mice were injected with the same suspension. In protected mice, multiplication occurred after the first $24 \mathrm{hr}$. although at a lower rate than in unprotected mice. Multiplication reached its height on the 


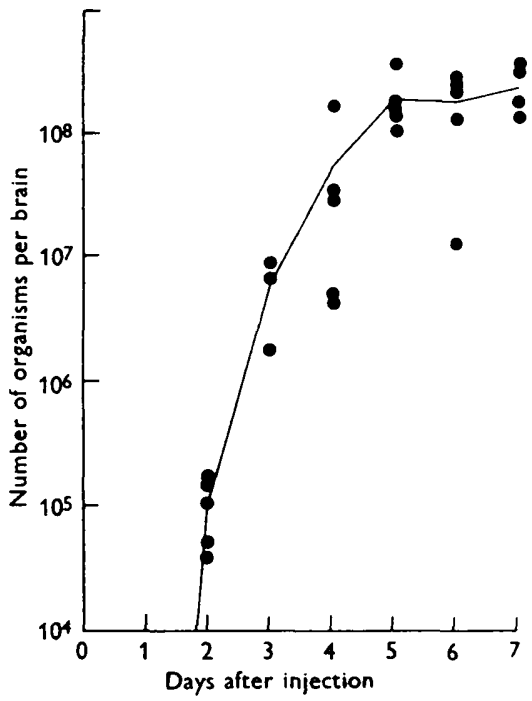

Fig. 1

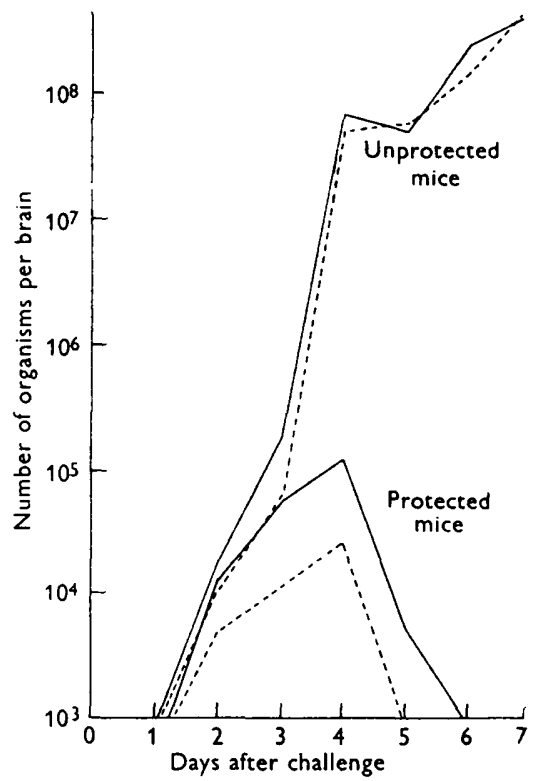

Fig. 2

Fig. 1. Number of organisms/brain after injection of 5000 organisms through the foramen magnum. Five brains were examined daily (two rejected on 3rd day and one on 7th day because of contamination).

Fig. 2. Number of organisms/brain after injection of 5,000 organisms intracranially in unprotected and protected mice (average of 3 brains daily). —_ Injected via foramen magnum; - . - . - injected via parietal bone.

Table 2. Permeability of the blood-brain barrier in normal mice and in mice which had been infected intracranially with Bordetella pertussis 6 days earlier

\section{Interval between \\ injection of \\ radio-iodinated \\ albumin and} death $(\mathrm{hr})$

Exp. 1

(means of

3 mice)

Radio-
activity
of serum
(c.p.m./ml.)
$(a)$

Controls

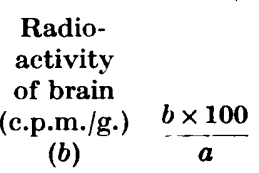

\begin{tabular}{|c|c|c|}
\hline \multicolumn{3}{|c|}{ Infected } \\
\hline $\begin{array}{c}\text { Radio- } \\
\text { activity } \\
\text { of serum } \\
\text { (c.p.m. } / \mathrm{ml} \text {.) }\end{array}$ & $\begin{array}{l}\text { Radio- } \\
\text { activity } \\
\text { of brain } \\
\text { (c.p.m./g.) }\end{array}$ & $b \times 100$ \\
\hline$(a)$ & $(b)$ & \\
\hline
\end{tabular}

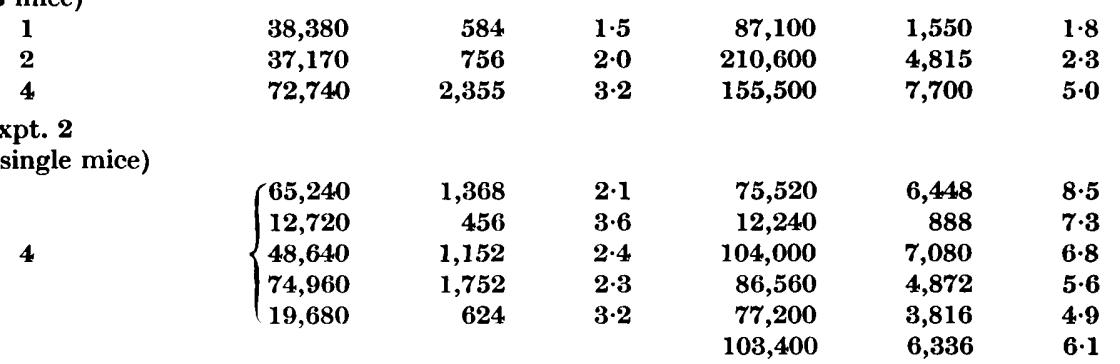

Note: The infected mice were smaller than the controls owing to impaired growth following the infection. Consequently the serum levels of radioactivity are higher in these mice, since all mice were given the same dose of labelled protein. 
4th or 5th day, levels ranging from 50,000 to $7 \times 10^{6}$ organisms/brain. After this the organisms were eliminated; and this process took from 1 to five days. There was no striking difference in counts between animals injected intracerebrally and those injected through the foramen magnum.

\section{Changes in the blood-brain barrier}

One possible cause of the hydrocephalus which was such a striking feature in the brains of mice dying from the infection was an increased permeability of the blood-brain barrier. In Table 2 the results of two representative experiments are given which suggest that this did occur. Four hr. after injecting a labelled protein intraperitoneally the ratio of radioactivity in the brain to that in the serum was significantly higher in mice in the final stages of the infection.

\section{DISCUSSION}

This investigation was undertaken to study the sequence of changes in unprotected mice after intracranial challenge with Bordetella pertussis and to elucidate the cause of death. Subsequently we wished to show how these changes differed from those observed in immunized mice and thereby to throw some light on the nature of their immunity. When mice were challenged intracranially, the bacteria were distributed throughout the subarachnoid space and ventricles; although some entered the blood stream, they did not multiply outside the cranial cavity. After a period during which the injected organisms effectively 'disappeared', they began to multiply in the ventricular fluid and went on multiplying, although at a steadily decreasing rate, until the death of the animal. Multiplication was confined to the ventricles and there was no invasion of the cerebral substance.

There was a striking localization of the bacteria to the cilia of the ventricles. This is reminiscent of that seen in the work of Arnheim (1903) and of Mallory \& Hornor (1912), who showed that in human cases of pertussis the bacteria were mainly found among the bronchial and tracheal cilia. A similar localization was found in experimental pertussis of puppies (Mallory, Hornor \& Henderson, 1913), monkeys (Sauer \& Hambrecht, 1929; Sprunt, Martin \& McDearman, 1938) and mice (Burnet \& Timmins, 1937). Gallavan \& Goodpasture (1937) showed that in chick embryos infected with Bordetella pertussis the organism grew among the cilia of the respiratory tract and of the transiently ciliated pharynx and oesophagus. The reason for this characteristic localization on ciliated epithelium is not at present clear.

Associated with bacterial multiplication was a steadily progressing purulent meningitis and choroiditis, with involvement of the perivascular spaces and the brain parenchyma. Similar appearances were noted in guinea-pigs after intracerebral injection of pertussis endotoxin by Fonteyne \& Dagnelie (1932). The haemorrhages, which were a conspicuous feature, suggest vascular damage by a toxic component of the bacteria or perhaps by the products of tissue break-down.

Many factors probably go to cause the hydrocephalus. Ventricular obstruc- 


\section{Infection of mice with Bordetella pertussis}

tion by pus cells is one. The experiments in which radio-iodinated human serum albumin was injected showed an increased permeability of the blood-brain barrier in the terminal stage of the infection, perhaps due to release of bacterial endotoxin (Eckman, King \& Brunson, 1958). Severe inflammation of the choroid plexuses, with impairment of the blood-cerebrospinal fluid barrier, was probably also a contributing factor.

It would seem, then, that the most likely cause of death in unprotected mice is a progressive cerebral infection with increasing brain damage. In immunized mice, on the other hand, although there is some multiplication of organisms, this is rapidly brought to a stop and the organisms are eliminated. Our work so far has not clearly indicated what factors are responsible for the destruction of the organisms. It is associated with a local accumulation of lymphocytes, mononuclear cells and plasma cells, which suggests that there is a local immune response to the injected bacteria.

We thank Dr K. Gal, Mr W. A. Cope, Mr J. Dunnington and Mr C. Robinson for technical assistance and Mr D. F. Boxall for taking the photographs.

\section{REFERENCES}

Arnheim, G. (1903). Pathogenese des Keuchheustens. Berl. klin. Wschr. 40, 685.

Burnet, F. M. \& Timmins, C. (1937). Experimental infection with Haemophilus pertussis in the mouse by intranasal inoculation. Brit. J. exp. Path. 18, 83.

Eckman, P., King, W. \& Brunson, J. (1958). Effect of endotoxin on the blood brain barrier. Fed. Proc. 17, 435.

Fonteyne, P. \& Dagnelie, J. (1932). Action de l'endotoxine coquelucheuse sur les centres nerveux. Recherches expérimentales. J. Neurol. Psychiat. 32, 660.

Gallavan, M. \& Goodpasture, E. W. (1937). Infection of chick embryos with $H$. pertussis reproducing pulmonary lesions of whooping cough. Amer. J. Path. 13, 927.

Kendrick, P. L., Eldering, G., Dixon, M. K. \& Misner, J. (1947). Mouse protection tests in the study of pertussis vaccine. Amer. J. publ. Hlth, 37, 803.

Mallory, F. B. \& Hornor, A. A. (1912). Pertussis: the histological lesion in the respiratory tract. J. med. Res. $27,115$.

Mallory, F. B., Hornor, A. A. \& Henderson, F. F. (1913). The relation of the Bordet-Gengou bacillus to the lesion of pertussis. J. med. Res. 27, 391.

Medical Research Council (1956). Report on vaccination against whooping cough. Brit. med. J. 2, 454.

Pearse, A. G. E. (1953). Histochemistry, Theoretical and Applied. London: J. and A. Churchill.

Pearse, A. G. E. (1955). Copper phthalocyanins as phospholipid stains. J. Path. Bact. 70, 554.

Pearson, B. \& Defendi, V. (1954). Histochemical demonstration of succinic dehydrogenase in thin tissue sections, by means of 2-( $p$-iodophenyl)-3- $(p$ nitrophenyl)-5-phenyl tetrazolium chloride under aerobic conditions. J. Histochem. Cytochem. 2, 248.

Rosa, C. G. \& Velardo, J. T. (1954). Histochemical demonstration of succinic dehydrogenase activity in tissue sections by a modified technique. J. Histochem. Cytochem. 2, 110.

Sauer, L. W. \& Hambrecht, L. (1929). Whooping cough. The site of the lesion. Arch. Path. 8, 944. 
Sprunt, D. H., Martin, D. S. \& McDearman, S. (1938). Results of the intratracheal injection of the Bordet-Gengou bacillus in the monkey and rabbit. J.exp. Med. 67, 309.

Ungar, J., James, A. M., Muggleton, P. W., Pegler, H. F. \& Tomich, E. G. (1950). The cultivation of Haemophilus pertussis in partially defined liquid media. J. gen. Microbiol. 4, 345.

\section{EXPLANATION OF PLATES}

Plate 1

Fig. 1. A cluster of Bordetella pertussis in the supra-optic recess of the third ventricle. Two days after inoculation. Giemsa; $\times \mathbf{2 0 0 0}$.

Fig. 2. Polymorphonuclear exudate in the basal meninges. Three days after inoculation. $\times 650$.

Fig. 3. Polymorphs cuffing vessels and invading the brain substance in the hypothalamus. Three days after inoculation. $\times 400$.

Fig. 4. B. pertussis entangled in the ependymal cilia. Four days after inoculation. Giemsa ; $\times 1775$.

Fig. 5. Focal loss of cells in the granular layer of the cerebellum. Five days after inoculation. $\times 250$.

Fig. 6. The lateral ventricle distended with purulent fluid: numerous haemorrhages in the surrounding brain tissue. Seven days after inoculation. Mallory trichrome; $\times 70$.

\section{Plate 2}

Fig. 7. The wall of the lateral ventricle showing a thick layer of organisms adherent to the disorganized ependyma. The ventricular cavity, containing purulent fluid, is in the lower part of the figure. Six days after inoculation. Giemsa; $\times 500$.

Fig. 8. Mononuclear meningeal exudate in an immune mouse. Six days after challenge. $\times 650$.

Fig. 9. Perivascular cuffing in an immune mouse seven days after challenge. $\times 250$.

Fig. 10. Several plasma cells in the meningeal exudate of an immune mouse. Eight days after challenge. $\times 1360$.

Fig. 11. A mitotic figure and plasma cells in the meninges of an immune mouse. Eight days after challenge. $\times 1025$.

Fig. 12. A small granuloma in the fourth ventricle of an immune mouse. Nine days after challenge. $\times 500$. 
Journal of Gemeral Microbiology, Vol. 22, No. 2
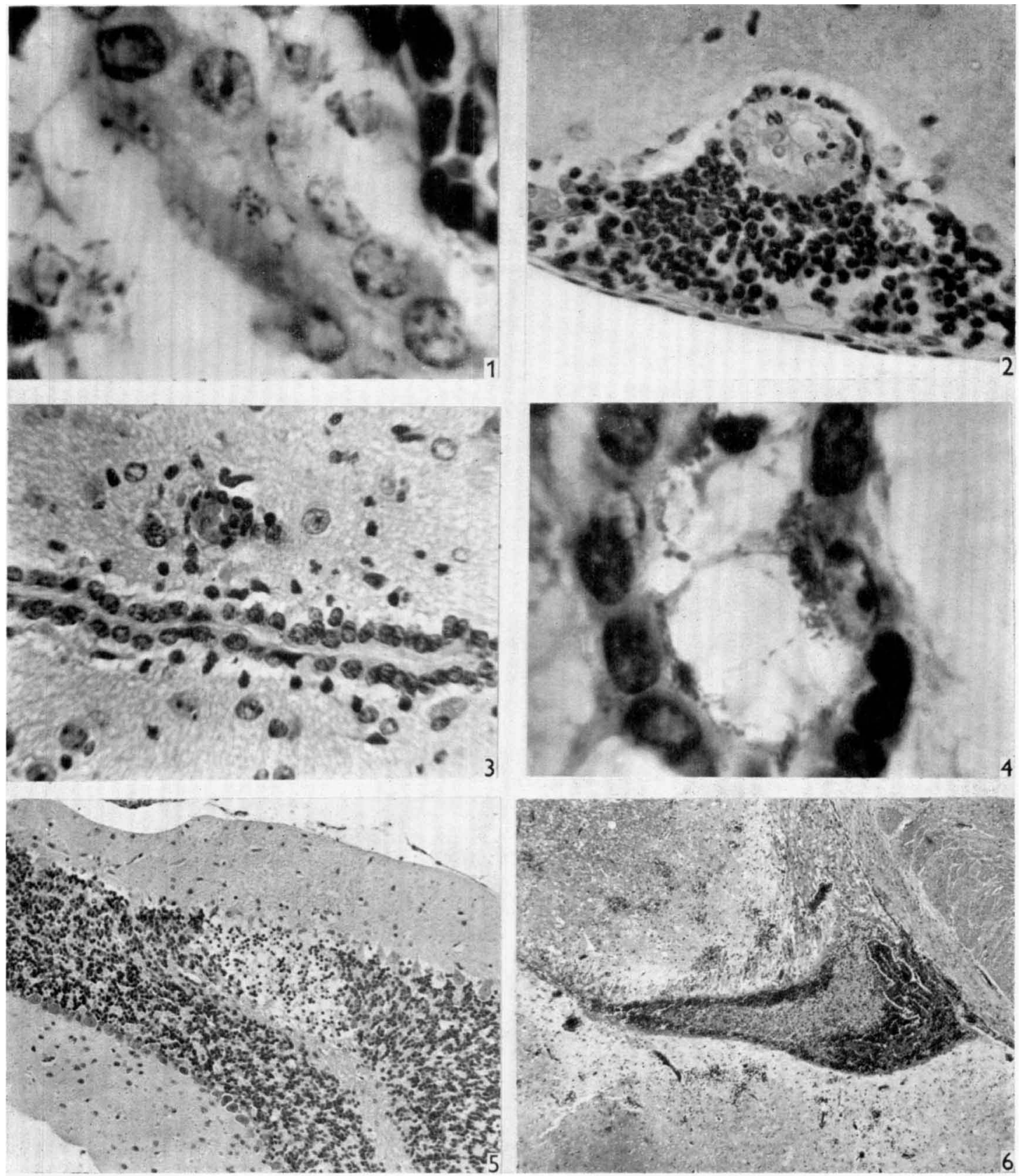

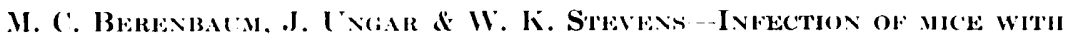

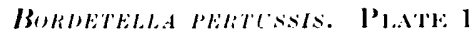


Journal of General Microbiology, Vol. 22, No. 2
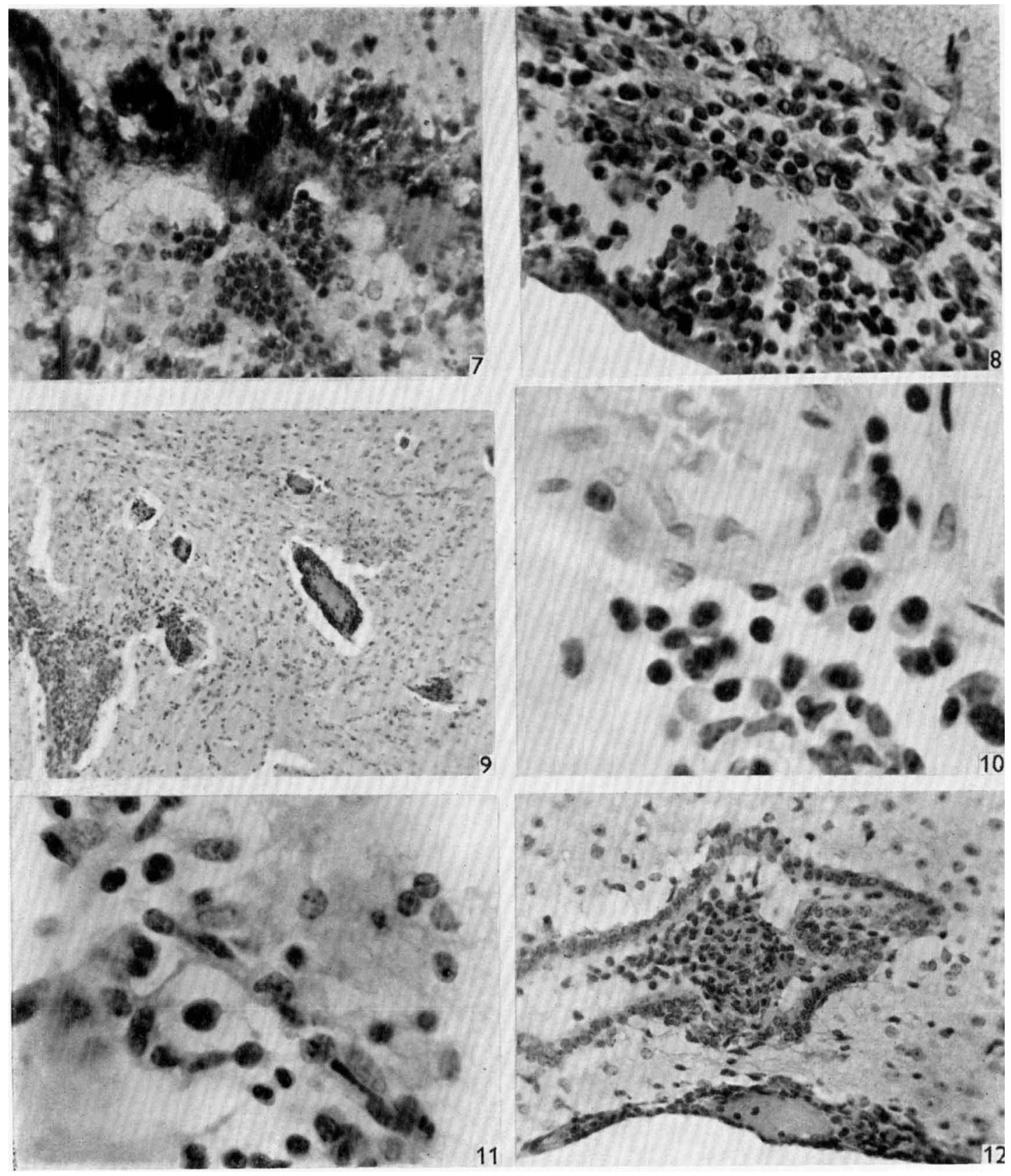

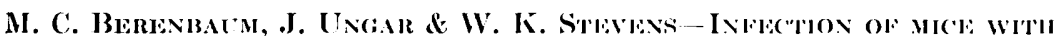
Bordetella pertessis. Plate: 